\title{
Meningkatkan Kemampuan Guru-Guru Fisika Dalam Membuat Kisi-Kisi Soal Melalui Teknik Kelompok SMA Se-Kabupaten Pohuwato
}

\author{
Minarsih \\ Pengawas SMA/SMK Provinsi Gorontalo \\ minarsih@gmail.com
}

Received: 12 Januari 2021; Revised: 26 Februari 2021; Accepted: 28 April 2021

DOI: http://dx.doi.org/10.37905/aksara.7.2.191-200.2021

\begin{abstract}
ABSTRAK
Evaluasi merupakan salah satu kegiatan utama yang harus dilakukan oleh seorang guru dalam kegiatan pembelajaran. Dengan penilaian, guruakan mengetahui perkembangan hasil belajar, intelegensi, bakat khusus, minat, hubungan sosial, sikap dan kepribadian siswa atau peserta didik. Evaluasi memiliki beberapa tujuan, antara lain (a) untuk mengetahui kemajuan belajar siswa setelah mengikuti kegiatan pembelajaran dalam jangka waktu tertentu, (b) untuk mengetahui efektivitas metode pembelajaran yang digunakan, (c) untuk mengetahui kedudukan siswa dalam kelompoknya, dan (d) untuk memperoleh masukan atau umpan balik bagi guru dan siswa dalam rangka perbaikan. Pelaksanaan evaluasi pembelajaran dapat dilakukan dengan menggunakan berbagai alat evaluasi, antara lain, kuesioner, tes, skala, format observasi, dan lain-lain. Dari sekian banyak alat evaluasi, secara umum dapat dikelompokkan menjadi dua, yakni alat tes dan nontes. Penilaian Berbasis Kelas (PBK) merupakan salah satu model dalam kegiatan evaluasi untuk menilai kemajuan belajar siswa. Dalam konteks ini Penilaian Berbasis Kelas (PBK) merupakan suatu proses pengumpulan, pelaporan, dan penggunaan informasi tentang hasil belajar siswa dengan menerapkan prinsip-prinsip penilaian berkelanjutan, otentik, akurat, dan konsisten dalam kegiatan pembelajaran di bawah kewenangan guru di kelas.

Kata Kunci : Evaluasi, konteks
\end{abstract}

\begin{abstract}
Evaluation is one of the main activities that must be carried out by a teacher in learning activities. With the assessment, the teacher will know the development of learning outcomes, intelligence, special talents, interests, social relationships, attitudes and personalities of students or students. Evaluation has several objectives, including (a) to determine the progress of student learning after participating in learning activities within a certain period of time, (b) to determine the effectiveness of the learning methods used, (c) to determine the position of students in the group, and (d) to get input or feedback for teachers and students in order to improve. Implementation of learning evaluation can be done using various evaluation tools, including questionnaires, tests, scales, observation formats, and others. Of the many evaluation tools, in general, they can be grouped into two, namely test and non-test tools. Class-Based Assessment (PBK) is a model in evaluation activities to assess student learning progress. In this context Class-Based Assessment $(P B B)$ is a process of collecting, reporting, and using information about student learning outcomes by applying the principles of continuous, authentic, accurate, and consistent assessment in learning activities under the authority of teachers in the classroom. Keywords: Evaluation, context
\end{abstract}




\section{PENDAHULUAN}

Penilaian Berbasis Kelas (PBK) merupakan suatu proses pengumpulan, pelaporan, dan penggunaan informasi tentang hasil belajar siswa dengan menerapkan prinsip-prinsip penilaian berkelanjutan, otentik, akurat, dan konsisten dalam kegiatan pembelajaran di bawah kewenangan guru di kelas. PBK mengidentifikasi pencapaian kompetensi dan hasil belajar yang dikemukakan melalui pernyataan yang jelas tentang standar yang harus dan telah dicapai disertai dengan peta kemajuan belajar siswa dan pelaporan. Bila selama dekade terakhir ini keberhasilan belajar siswa hanya ditentukan oleh nilai ujian akhir (UAN), maka dengan diberlakukannya PBK hal itu tidak terjadi lagi. Naik atau tidak naik dan lulus atau tidak lulus siswa sepenuhnya menjadi tanggung jawab guru (sekolah) berdasarkan kemajuan proses dan hasil belajar siswa di sekolah bersangkutan. Dalam hal ini kewenangan guru menjadi sangat luas dan menentukan. Karenanya, peningkatan kemampuan profesional dan integritas moral guru dalam PBK merupakan suatu keniscayaan, agar terhindar dari upaya manipulasi nilai siswa. PBK menggunakan arti penilaian sebagai "assessment", yaitu kegiatan yang dilakukan untuk memperoleh dan mengefektifkan informasi tentang hasil belajar siswa pada tingkat kelas selama dan setelah kegiatan pembelajaran.

\section{KAJIAN TEORETIS}

\section{Pengertian Evaluasi Pembelajaran}

Sesungguhnya, dalam konteks penilaian ada beberapa istilah yang digunakan, yakni pengukuran, assessment dan evaluasi. Pengukuran atau measurementmerupakan suatu proses atau kegiatan untuk menentukan kuantitas sesuatu yang bersifat numerik. Pengukuran lebih bersifat kuantitatif, bahkan merupakan instrumen untuk melakukan penilaian. Unsur pokok dalam kegiatan pengukuran ini, antara lain adalahsebagai berikut: 1). tujuan pengukuran, 2). ada objek ukur, 3). alat ukur, 4). proses pengukuran, 5). hasil pengukuran kuantitatif. Sementara, pengertian asesmen (assessment) adalah kegiatan mengukur dan mengadakan estimasi terhadap hasil pengukuran atau membanding-bandingkan dan tidak sampai ke taraf pengambilan keputusan. Sedangkan evaluasi secara etimologi berasal dari bahasa Inggeris evaluationyang bertarti value, yang secara secara harfiah dapat diartikan sebagai penilaian.Namun, dari sisi terminologis ada beberapa definisi yang dapat dikemukakan, yakni: a).Suatu proses sistematik untuk mengetahui tingkat keberhasilan sesuatu. b).Kegiatan untuk menilai sesuatu secara terencana, sistematik dan terarah berdasarkan atas tujuan yang jelas. c).Proses penentuan nilai berdasarkan data kuantitatif hasilpengukuran untuk keperluan pengambilan keputusan. Berdasarkan pada berbagai batasan 3 jenis penilaian di atas, maka dapat diketahui bahwa perbedaan antara evaluasi dengan pengukuran adalah dalam hal jawaban terhadap pertanyaan "what value" untuk evaluasi dan "how much" untuk pengukuran. Adapun asesmen berada di antara kegiatan pengukuran dan evaluasi. Artinya bahwa sebelum melakukan asesmen ataupun evaluasi lebih dahulu dilakukan pengukuran. Sekalipun makna dari ketiga istilah (measurement, assessment, evaluation) secara teoretik definisinya berbeda, namun 
dalam kegiatan pembelajaran terkadang sulit untuk membedakan dan memisahkan batasan antara ketiganya, dan evaluasi pada umumnya diawali dengan kegiatan pengukuran (measurement) serta pembandingan (assessment). Evaluasi merupakan salah satu kegiatan utama yang harus dilakukan oleh seorang guru dalam kegiatan pembelajaran. Dengan penilaian, guruakan mengetahui perkembangan hasil belajar, intelegensi, bakat khusus, minat, hubungan sosial, sikap dan kepribadian siswa atau peserta didik. Adapun langkah-langkah pokok dalam penilaian secara umum terdiri dari: (1) perencanaan, (2) pengumpulan data, (3) verifikasi data, (4) analisis data, dan (5) interpretasi data.

Penilaian hasil belajar pada dasarnya adalah mempermasalahkan, bagaimana pengajar (guru) dapat mengetahui hasil pembelajaran yang telah dilakukan. Pengajar harus mengetahui sejauh mana pebelajar (learner) telah mengerti bahan yang telah diajarkan atau sejauh mana tujuan/kompetensi dari kegiatan pembelajaran yang dikelola dapat dicapai. Tingkat pencapaian kompetensi atau tujuan instruksional dari kegiatan pembelajaran yang telah dilaksanakan itu dapat dinyatakan dengan nilai

\section{Tujuan dan Fungsi Evaluasi}

Dalam konteks pelaksanaan pendidikan, evaluasi memiliki beberapa tujuan, antara lain sebagai berikut: 1).Untuk mengetahui kemajuan belajar siswa setelah mengikuti kegiatan pembelajaran dalam jangka waktu tertentu. 2).Untuk mengetahui efektivitas metode pembelajaran. 3).Untuk mengetahui kedudukan siswa dalam kelompoknya. 4).Untuk memperoleh masukan atau umpan balik bagi guru dan siswa dalam rangka perbaikan. Selain fungsi di atas, penilaian juga dapat berfungsi sebagai alat seleksi, penempatan, dan diagnostik,guna mengetahui keberhasilan suatu proses dan hasil pembelajaran. Penjelasan dari setiap fungsi tersebut adalah: a).Fungsi seleksi. Evaluasi berfungsi atau dilaksanakan untuk keperluan seleksi, yaitu menyeleksi calon peserta suatu lembaga pendidikan/kursus berdasarkan kriteria tertentu. b). Fungsi Penempatan. Evaluasi berfungsi atau dilaksanakan untuk keperluan penempatan agar setiap orang (peserta pendidikan) mengikuti pendidikan pada jenis dan/atau jenjang pendidikan yang sesuai dengan bakat dan kemampuannya masing-masing. c). Fungsi Diagnostik. Evaluasi diagnostik berfungsi atau dilaksanakan untuk mengidentifikasi kesulitan belajar yang dialami peserta didik, menentukan faktor-faktor yang menyebabkan terjadinya kesulitan belajar, dan menetapkan cara mengatasi kesulitan belajar tersebut.

\section{Penilaian Berbasis Kelas}

Penilaian Berbasis Kelas (PBK) merupakan suatu proses pengumpulan, pelaporan, dan penggunaan informasi tentang hasil belajar siswa dengan menerapkan prinsip-prinsip penilaian berkelanjutan, otentik, akurat, dan konsisten dalam kegiatan pembelajaran di bawah kewenangan guru di kelas. PBK mengidentifikasi pencapaian kompetensi dan hasil belajar yang dikemukakan melalui pernyataan yang jelas tentang standar yang harus dan telah dicapai disertai dengan peta kemajuan belajar siswa dan pelaporan. Bila selama dekade terakhir ini keberhasilan belajar siswa hanya ditentukan oleh nilai ujian akhir (UAN), maka dengan diberlakukannya PBK hal itu tidak terjadi lagi. Naik atau tidak naik dan 
lulus atau tidak lulus siswa sepenuhnya menjadi tanggung jawab guru (sekolah) berdasarkan kemajuan proses dan hasil belajar siswa di sekolah bersangkutan. Dalam hal ini kewenangan guru menjadi sangat luas dan menentukan. Karenanya, peningkatan kemampuan profesional dan integritas moral guru dalam PBK merupakan suatu keniscayaan, agar terhindar dari upaya manipulasi nilai siswa.

PBK menggunakan arti penilaian sebagai "assessment", yaitu kegiatan yang dilakukan untuk memperoleh dan mengefektifkan informasi tentang hasil belajar siswa pada tingkat kelas selama dan setelah kegiatan pembelajaran. Data atau informasi dari penilaian di kelas ini merupakan salah satu bukti yang digunakan untuk mengukur keberhasilan suatu program pendidikan. PBK merupakan bagian dari evaluasi pendidikan karena lingkup evaluasi pendidikan secara umum jauh lebih luas dibandingkan PBK. (Lihat gambar 2).

\section{Prinsip-prinsip PBK}

Sebagai bagian dari kurikulum berbasis kompetensi, pelaksanaan PBK sangat dipengaruhi oleh berbagai faktor dan komponen yang ada di dalamnya. Namun demikian, guru mempunyai posisi sentral dalam menentukan keberhasilan dan kegagalan kegiatan penilaian. Untuk itu, dalam pelaksanaan penilaianharus memperhatikan prinsip-prinsip berikut:

a. PBK harus mengukur obyek yang seharusnya diukur dengan menggunakan jenis alat ukur yang tepat atau sahih (valid). Artinya, ada kesesuaian antara alat ukur dengan fungsi pengukuran dan sasaran pengukuran. Apabila alat ukur tidak memiliki kesahihan yang dapat dipertanggungjawabkan, maka data yang masuk salah sehingga kesimpulan yang ditarik juga besar kemungkinan menjadi salah.

b. Mendidik. PBK harus memberikan sumbangan positif pada pencapaian hasil belajar siswa. Oleh karena itu, PBK harus dinyatakan dan dapat dirasakan sebagai penghargaan untuk memotivasi siswa yang berhasil (positive reinforcement) dan sebagai pemicu semangat untuk meningkatkan hasil belajar bagi yang kurang berhasil (negative reinforcement), sehingga keberhasilan dan kegagalan siswa harus tetap diapresiasi dalam penilaian.

c. Berorientasi pada kompetensi. PBK harus menilai pencapaian kompetensi siswa yang meliputi seperangkat pengetahuan, sikap, dan ketrampilan/nilai yang terefleksikan dalam kebiasaan berfikir dan bertindak. Dengan berpijak pada kompetensi ini, maka ukuran-ukuran keberhasilan pembelajaran akan dapat diketahui secara jelas dan terarah.

d. Adil dan obyektif. PBK harus mempertimbangkan rasa keadilan dan obyektivitas siswa, tanpa membeda-bedakan jenis kelamin, latar belakang budaya, dan berbagai hal yang memberikan kontribusi pada pembelajaran. Sebab ketidakadilan dalam penilaian, dapat menyebabkan menurunnya motivasi belajar siswa, karena merasa dianaktirikan.

e. Terbuka. PBK hendaknya dilakukan secara terbuka bagi berbagai kalangan (stakeholders) baik langsung maupun tidak langsung, sehingga keputusan tentang keberhasilan siswa jelas bagi pihak-pihak yang berkepentingan, tanpa ada rekayasa atau sembunyi-sembunyi yang dapat merugikan semua pihak. 
f. Berkesinambungan. PBK harus dilakukan secara terus-menerus atau berkesinambungan dari waktu ke waktu, untuk mengetahui secara menyeluruh perkembangan siswa, sehingga kegiatan dan unjuk kerja siswa dapat dipantau melalui penilaian.

\section{METODE PENELITIAN}

Subjek dalam penelitian ini adalah guru-guru FisikaSMA Se-Kabupaten Pohuwato. Penelitian ini dilaksanakan mengingat bahwa kemampuan guru-guru fisikaSMA Se-Kabupaten Pohuwato dalam membuat kisi-kisi belum optimal. Oleh karenanya peneliti memandang bahwa kemampuan guru-guru kelas dalam membuat kisi-kisi soal perlu ditingkatkan melalui teknik bimbingan kelompok.

Variabel dalam penelitian ini adalah sebagai berikut. Variabel Input yaitu adalah sebagai berikut: a) Guru-guru fisika SMA Se-Kabupaten Pohuwato yang menjadi subjek penelitian b ) Fasilitas yang digunakan dalam penelitian. Variabel proses adalah peningkatan kemampuan guru dalam membuat kisi-kisi soal dengan indikator: Kemampuan guru-guru fisika SMA se-kabupaten pohuwato mengidentifikasi kompetensi dasar dan Kemampuan guru-gurufisika SMA sekabupaten pohuwatomenganalisis ranah kognitif, afektif dan psikomotorik.

Untuk mendapatkan data yang akurat dalam penelitian ini digunakan model pengumpulan data sebagai berikut: 1) Observasi. Teknik ini dilakukan dengan cara melakukan pengamatan terhadap proses pembimbingan yang dilakukan guru dengan menggunakan teknik bimbingan kelompok. 2). Dokumentasi. Teknik dokumentasi dilakukan untuk mengumpulkan data dengan melihat dokumen kemampuan guru dalam membuat kisi-kisi soal.

\section{HASIL PENELITIAN DAN PEMBAHASAN \\ Kegiatan Observasi Awal}

Sebelum peneliti melaksanakan kegiatan penelitian maka terlebih dahulu dilakukan kegiatan observasi awal untuk untuk melihat kondisi riil tentang kemampuan guru dalam membuat kisi-kisi soal. Hasil observasi terkait kemampuan guru dalam membuat kisi-kisi soal pada observasi awal ditampilkan pada tabel di bawah ini:

Tabel 1. Kemampuan guru-gurufisika SMA se-kabupaten pohuwatodalam Pembuatan kisi-kisi soal Tahap Observasi Awal

\begin{tabular}{|l|c|c|c|}
\hline \multicolumn{1}{|c|}{ Kriteria Aspek yang dinilai } & Baik & Cukup & $\begin{array}{c}\text { Kurang } \\
\text { Baik }\end{array}$ \\
\hline $\begin{array}{l}\text { Kemampuan guru mengidentifikasi } \\
\text { kompetensi dasar }\end{array}$ & $\sqrt{ }$ & - & - \\
\hline $\begin{array}{l}\text { Kemampuan guru menganalisis ranah } \\
\text { kognitif, afektif dan psikomotorik }\end{array}$ & $\sqrt{ }$ & - & - \\
\hline $\begin{array}{l}\text { Kemampuan guru dalam membuat } \\
\text { penyebaran soal yang rasional }\end{array}$ & - & $\sqrt{ }$ & - \\
\hline $\begin{array}{l}\text { Kemampuan guru dalam melakukan } \\
\text { analisis tingkat kesulitan soal }\end{array}$ & - & - & $\sqrt{ }$ \\
\hline
\end{tabular}




\begin{tabular}{|c|c|c|c|}
\hline $\begin{array}{l}\text { Kemampuan guru dalam merancang soal } \\
\text { sesuai dengan kisi-kisi }\end{array}$ & - & - & $\sqrt{ }$ \\
\hline Jumlah & 2 & 1 & 2 \\
\hline$\%$ & $40 \%$ & $20 \%$ & $40 \%$ \\
\hline
\end{tabular}

Keterangan:

Baik

Skor $85-100$

\section{Cukup}

Skor 60-84
Kurang Baik

Skor $<59$

Tabel 1 di atas menunjukkan bahwa kemampuan guru dalam membuat kisi-kisi soal sangat rendah hal ini ditunjukkan dengan rendahnya kemampuan guru dalam beberapa hal sebagai berikut yaitu: 1) guru pada umumnya belum mampu melakukan analisis tingkat kesulitan soal, 2) Guru belum mampu dalam merancang soal sesuai dengan kisi-kisi. serta, 3) guru kurang optimal dalam membuat penyebaran soal yang rasional. Tabel 1 juga menunjukkan bahwa terdapat 2 komponen yang sangat baik dikuasai guru yaitu 1) kemampuan guru mengidentifikasi kompetensi dasar, dan 2) kemampuan guru menganalisis ranah kognitif, afektif dan psikomotorik

\section{Kegiatan Siklus I}

\section{1). Perencanaan}

Kegiatan sklus i dilaksanakan dengan tahapan sebagai berikut:

Kegiatan perencanaan dilakukan dengan cara:

a. Menyusun lembar observasi dan melakukan observasi awal terhadap subjek penelitian.

b. Membuat rencana pelaksanaan bimbingan kelompok bersama dengan guru untuk meningkatkan kemampuan guru dalam membuat kisi-kisi soal.

\section{2). Pelaksanaan}

Pelaksanaan tindakan siklus I dilakukan dengan mengamati bimbingan kelompok yang dilaksanakan. Pengamatan difokuskan pada peningkatan kemampuan guru dalam meningkatkan kemampuan guru dalam membuat kisi-kisi soal. Proses bimbingan kelompok yang dilakukan mengacu pada rencana yang telah dirumuskan.

\section{3). Refleksi}

Dari hasil observasi diperoleh persentase capaian kemampuan guru dalam membuat kisi-kisi soal siklus I di tampilkan dalam tabel berikut:

Tabel 2. Kemampuan Guru-guru fisika SMA se-kabupaten pohuwatodalam Membuat kisi-kisi soal Pada Siklus I

\begin{tabular}{|l|c|c|c|}
\hline \multicolumn{1}{|c|}{ Kriteria Aspek yang dinilai } & Baik & Cukup & $\begin{array}{c}\text { Kurang } \\
\text { Baik }\end{array}$ \\
\hline $\begin{array}{l}\text { Kemampuan guru mengidentifikasi } \\
\text { kompetensi dasar }\end{array}$ & $\sqrt{ }$ & - & - \\
\hline $\begin{array}{l}\text { Kemampuan guru menganalisis ranah } \\
\text { kognitif, afektif dan psikomotorik }\end{array}$ & $\sqrt{ }$ & - & - \\
\hline
\end{tabular}




\begin{tabular}{|l|c|c|c|}
\hline $\begin{array}{l}\text { Kemampuan guru dalam membuat } \\
\text { penyebaran soal yang rasional }\end{array}$ & $\sqrt{ }$ & - & - \\
\hline $\begin{array}{l}\text { Kemampuan guru dalam melakukan } \\
\text { analisis tingkat kesulitan soal }\end{array}$ & - & $\sqrt{ }$ & - \\
\hline $\begin{array}{l}\text { Kemampuan guru dalam merancang soal } \\
\text { sesuai dengan kisi-kisi }\end{array}$ & - & $\sqrt{ }$ & - \\
\hline Jumlah & 3 & 2 & - \\
\hline$\%$ & $60 \%$ & $40 \%$ & - \\
\hline
\end{tabular}

Keterangan:

Baik

Skor $85-100$
Cukup

Skor 60-84
Kurang Baik

Skor $<59$

Dari data hasil observasi selanjutnya dijadikan sebagai acuan bagi guru untuk dapat mengevaluasi dan merefleksi. Dengan demikian maka guru memiliki standar yang dapat digunakan untuk menilai tingkat kemampuannya dalam dalam membuat kisi-kisi soal. Tabel 2 di atas menunjukkan bahwa kemampuan guru dalam membuat kisi-kisi soal mengalami peningkatan setelah guru mendapatkanbimbingan kelompok. Hal ini ditunjukkan dengan meningkatnya kemampuan guru-guru fisia SMA se-kabupaten pohuwato dalam menguasai komponen pembuatan kisi-kisi soal. Dari 5 komponen utama yang diharapkan dapat dikuasai guru ternyata sebanyak 3 komponen (60\% yang dapat dikuasai guru dengan baik) yaitu a) kemampuan guru mengidentifikasi kompetensi dasar, b) kemampuan guru menganalisis ranah kognitif, afektif dan psikomotorik, dan c) kemampuan guru dalam membuat penyebaran soal yang rasional. Tabel 2 juga menunjukkan bahwa terdapat 2 komponen yang cukup dikuasai guru dengan baik. Komponen tersebut adalah yaitu 1) kemampuan guru dalam melakukan analisis tingkat kesulitan soal, dan 2) kemampuan guru dalam merancang soal sesuai dengan kisi-kisi.

Berdasarkan temuan dari kegiatan siklus I maka perlu dilakukan tindakan untuk siklus II mengingat bahwa penguasaan guru terhadap kemampuan yang diharapkan belum mencapai indicator kinerja yang diharapkan. Kegiatan siklus II dengan fokus pada upaya perbaikan dan peningkatan kemampuan guru dalam membuat kisi-kisi soal. Melalui upaya ini diharapkan mampu meningkatkan kemampuan guru dalam membuat kisi-kisi soalyang berkualitas.

\section{Kegiatan Siklus II}

\section{1). Perencanaan}

Kegiatan perencanaan pada siklus II dilaksanakan mengacu pada kelemahan yang dilakukan guru pada siklus I. Dalam kegiatan perencanaan ini fokus pada perbaikan strategi yang digunakan guru dalam meningkatkan kemampuan guru dalam membuat kisi-kisi soal. Perencanaan pada siklus II dilakukan dengan langkah sebagai berikut:

Kegiatan perencanaan dilakukan dengan cara:

1. Menyusun lembar observasi dan melakukan observasi awal terhadap subjek penelitian. 
2. Membuat rencana pelaksanaan bimbingan kelompok bersama dengan guru untuk meningkatkan kemampuan guru-guru fisika se-kabupaten pohuwatodalam membuat kisi-kisi soal.

3. Memfasilitasi guru untuk mengikuti kegiatan bimbingan kelompok

4. Memfasilitasi guru untuk meningkatkan kemampuan dalam membuat kisikisi soal.

5. Merencanakan kegiatan tindak lanjut

\section{2). Pelaksanaan}

Pelaksanaan tindakan pada siklus II dilakukan dengan mengadakan pengamatan terhadap guru membelajarkan siswa dengan meningkatkan kemampuan guru dalam membuat kisi-kisi soal. Dalam melaksanakan kegiatan siklus II ini guru melakukan kegiatan bimbingan kelompok dengan langkahlangkah sebagai berikut:

1) Melakukan perencanaan kegiatan bimbingan kelompok siklus II tentang peningkatan kompetensi guru dalam membuat kisi-kisi soal.

2) Melaksanakan kegiatan bimbingan kelompok sesuai dengan rencana yang telah dijadwalkan

3) Melakukan kegiatan diskusi balikan untuk mengukur kemampuan guru dalam pembuatan kisi-kisi soal.

4) Melakukan kegiatan diskusi balikan

5) Melakukan evaluasi terhadap kegiatan bimbingan kelompok yang dilakukan.

\section{3). Refleksi}

Berdasarkan hasil refleksi menunjukkan bahwa terjadi peningkatan kemampuan guru dalam meningkatkan kemampuan guru dalam membuat kisi-kisi soal. Dalam konteks ini kegiatan bimbingan kelompok yang dilakukan guru di kelas sudah sesuai dengan prosedur yang ditetapkan bersama.

\section{PEMBAHASAN}

Berdasarkan hasil penelitian tindakan sekolah yang dilaksanakan selama 2 siklus di SMA se-kabupaten pohuwatodiperoleh data hasil penelitian terkait peningkatan kemampuan guru dalam membuat kisi-kisi soal. Dari kegiatan siklus I menunjukkan bahwa kemampuan guru dalam membuat kisi-kisi soal mengalami peningkatan dari hasil observasi sebelumnya. Dalam konteks ini peningkatan tersebut terjadi karena dalam kegiatan bimbingan kelompok dilakukan secara baik dan mengacu pada prosedur operasional yang telah ditetapkan

Kondisi riil yang terjadi dari kegiatan pada siklus I untuk meningkatkan kemampuan siswa dalam melakukan kegiatan bimbingan belajara antara lain ditunjukkan dengan beberapa hal sebagai berikut:

1) Guru-guru kelas pada umumnya telah mampu mengidentifikasi kompetensi dasar sehingga menjadi dasar dalam penyusunan kisi-kisi soal

2) Guru-guru fiskaSMA se-kabupaten pohuwatopada umumnya telah mampu menganalisis ranah kognitif, afektif dan psikomotorik 
3) Guru-guru fiska SMA se-kabupaten pohuwatotelah mampu membuat penyebaran soal yang rasional

Dari hasil refleksi dan umpan balik yang dilakukan oleh guru para pengamat disimpulkan beberapa hal yang perlu diperbaiki dalam upaya meningkatkan kemampuan guru dalam membuat kisi-kisi soal sebagai berikut :

a. Masih terdapat dua komponen yang perlu ditingkatkan oleh guru-guru fiska SMA se-kabupaten pohuwatodalam membuat kisi-kisi soal.

b. Dalam proses penyusuna kisi-kisi guru-guru fiskaSMA se-kabupaten pohuwatoperlu melakukan analisis yang tajam terhadap berbagai hal yang mendukung peningkatan strategi dalam penyusunan kisi-kisi soal.

Berdasarkan hasil analisis ini menunjukkan bahwa terlihat perkembangan yang cukup signifikan dari kemampuan guru dalam membuat kisi-kisi soal. Namun demikian kemampuan guru dalam meningkatkan kemampuan guru-gurufisika SMA se-kabupaten pohuwatodalam membuat kisi-kisi soal perlu ditingkatkan karena terdapat 2 kemampuan dalam pembuatan kisi-kisi soal yang belum dapat dilaksanakan guru dengan baik. Dalam konteks ini guru belum menguasai dengan baik strategi dalam melaksanakan ke dua komponen tersebut.

Berdasarkan uraian di atas menunjukkan bahwa kemampuan guru-guru fisikaSMA se-kabupaten pohuwatodalam membuat kisi-kisi soal secara belum sesuai yang diharapkan. Hasil analisis ini menjadi dasar pelaksanaan tindakan pada siklus II. Kegiatan Siklus II dilakukan dengan mengingatkan guru tentang perlunya memiliki penguasaan atas komponen kemampuan guru dalam melakukan analisis tingkat kesulitan soal dan kemampuan guru-guru fisikaSMA se-kabupaten pohuwato 1 Paguyaman alam merancang soal sesuai dengan kisi-kisi. Dari kegiatan tindakan pada siklus II terlihat adanya perbedaan yang cukup signifikan dengan aktivitas yang dilakukan guru pada siklus I. Dalam hal ini aktivitas guru mengalami peningkatan kemampuan dalam melakukan analisis tingkat kesulitan soal dan merancang soal sesuai dengan kisi-kisi. Peningkatan kemampuan ini terjadi karena guru secara intensif memberikan perhatian terhadap aspek yang masih kurang terkait kemampuan guru fisikaSMA se-kabupaten pohuwatodalam membuat kisi-kisi soal. Melalui kegiatan ini maka guru semakin cermat dan teliti yang pada akhirnya mampu meningkatkan kemampuan gurufisika SMA sekabupaten pohuwatodalam membuat kisi-kisi soal.

Berdasarkan kegiatan refleksi dan umpan balik yang dilakukan antara guru dan guru serta kepala sekolah disepakati untuk tidak melanjutkan penelitian ke siklus III karena guru tersebut pada dasarnya telah dapat membuat kisi-kisi soal dengan baik sesuai kriteria yang diharapkan.

\section{PENUTUP} bahwa:

Berdasarkan deskripsi hasil penelitian dan pembahasan, dapat disimpulkan

1. Kemampuan guru-guru fisikaSMA se-kabupaten pohuwatodalam membuat kisi-kisi soal mengalami peningkatan setelah dikenai tindakan melalui II siklus. 
2. Peningkatan kemampuan guru-guru fisika SMA se-kabupaten pohuwatodalam dalam membuat kisi-kisi soal ditandai dengan penguasaan guru secara optimal terhadap 5 komponen yaitu a) kemampuan guru mengidentifikasi kompetensi dasar, b) kemampuan guru menganalisis ranah kognitif, afektif dan psikomotorik, c) kemampuan guru dalam membuat penyebaran soal yang rasional, d) kemampuan guru dalam melakukan analisis tingkat kesulitan soal, dan e) kemampuan guru dalam merancang soal sesuai dengan kisi-kisi

\section{B. Saran}

Dari hasil penelitian tindakan kelas ini, maka dapat dikemukakan saransaran sebagai berikut:

1. Guru-guru fisikaSMA se-kabupaten pohuwato perlu berlatih secara kontinu untuk meningkatkan kemampuannya dalam membuat kisi-kisi soal agar dapat menghasilkan kisi-kisi soal yang ideal.

2. Perlu komitmen yang tinggi dari para guru fisikaSMA se-kabupaten pohuwatountuk melakukan analisis terhadap kisi-kisi dan merancang soal yang berkualitas sesuai dengan kisi-kisi

3. Bimbingan kelompok bagi guru-guru fisika SMA se-kabupaten pohuwatosecara kontinu tentang prosedur dan mekanisme yang dapat dilakukan membuat kisi-kisi soal sehingga memutakhirkan kemampuan guru-guru tersebut dalam membuat kisi-kisi soal yang ideal

\section{DAFTAR PUSTAKA}

Agus Taufiq. 2007. Bimbingan kelompok Bimbingan dan Konseling (Bahan Pelatihan BK di Cikole). Bandung.

Binet. 2010. Layanan Bimbingan Belajar. (Online) Tersedia dihttp://jaringanilmupengetahuan.blogspot.com/2010/04/tujuan-layananbimbingan-belajar.sadja.html

Iim Waliman, dkk. 2001. Bimbingan kelompok(Modul Manajemen Berbasis Sekolah). Bandung : Dinas Pendidikan Provinsi Jawa Barat

Joni, T. Raka. 2004. Pedoman Umum Alat Penilaian Kemampuan Guru. Jakarta: Dirjen Pendidikan Tinggi Depdikbud

Manullang. 1996. Dasar-Dasar Manajemen, Jakarta: Ghalia Indonesia

Mulyasa, 2003. Manajemen Berbasis Sekolah, Konsep, Strategi dan Implementasi. Bandung PT Remaja Rosda Karya

Purwanto, Ngalim, 1998, Administrasi Dan Supervisi Pendidikan, Bandung PT Remaja Rosda Karya

Sutisna, Oteng, 2000, Administrasi Pendidikan, Dasar Teoritis Untuk Praktek Profesional,Bandung: Angkasa

Siagian. 2009. Administrasi Dan Supervisi Pendidikan, Bandung PT Remaja RoSMAa Karya

Sudradjat Akhmad. 2007. Kesulitan Belajar Siswa dan Bimbingan Belajar(Online) Tersedia di http/www.kes.rtti.,com.press.html

Sukmawati. 2009. Interaksi Belajar Mengaajar. Jakarta: Rineka Cipta 
AKSARA: Jurnal Ilmu Pendidikan Nonformal

P-ISSN $\underline{2407-8018}$ E-ISSN $\underline{2721-7310}$ DOI prefix $\underline{10.37905}$

Volume 07 (02) Mei 2021

http://ejurnal.pps.ungac.id/index.php/Aksara 